\title{
Expired Desloratidine Drug as Inhibitor for Corrosion of Carbon Steel Pipeline in Hydrochloric acid Solution
}

\author{
Salah Eid ${ }^{1,2}$ \\ ${ }^{1}$ Chemistry Department, College of Science and Arts, Alqurayat,, Jouf University, Alqurayat, KSA \\ ${ }^{2}$ Chemistry Department, Faculty of science, Benha University, Benha, Egypt \\ E-mail: eedsalah@yahoo.com
}

doi: $10.20964 / 2021.01 .27$

Received: 18 August 2020 / Accepted: 2 November 2020 / Published: 30 November 2020

\begin{abstract}
The expired desloratidine drug was examined as an inhibitor for carbon steel (X52) corrosion in $1 \mathrm{M} \mathrm{HCl}$ solution. The inhibition conduct of desloratidine was studied utilizing potentiodynamic polarization and weight loss techniques. The drug efficacy as inhibitor was found to rise by increasing the desloratidine concentration and reduces by increasing temperature. Morphology of the surface and the adsorption isotherm were also studied. The heat of adsorption $\left(Q_{a d s}\right)$ and activation energy $\left(E_{a}\right)$ were computed and elucidated. Based on adsorption of desloratidine molecules on carbon steel surface leading to conserve the carbon steel surface from the offensive ions, the inhibition conduct was explicated.
\end{abstract}

Keywords: Reusing - Drug - Desloratidine - Carbon Steel - Corrosion - Inhibitor.

\section{$\underline{\text { FULL TEXT }}$}

(C) 2021 The Authors. Published by ESG (www.electrochemsci.org). This article is an open access article distributed under the terms and conditions of the Creative Commons Attribution license (http://creativecommons.org/licenses/by/4.0/). 